\title{
Correlation between sperm characteristics and testosterone in bovine seminal plasma by direct radioimmunoassay ${ }^{1}$
}

\section{Luiz Waldemar de Oliveira Souza ${ }^{2}$, André Furugen Cesar Andrade ${ }^{3}$, Eneiva Carla Carvalho Celeghini ${ }^{3}$, João Alberto Negrão ${ }^{4}$, Rubens Paes de Arruda ${ }^{5}$}

\author{
1 Research funded by FAPESP. \\ 2 Faculdades Integradas de Ourinhos, FIO, Fundação Educacional Miguel Mofarrej. \\ ${ }^{3}$ Departamento de Reprodução Animal, FMVZ, Universidade de São Paulo. \\ ${ }^{4}$ Departamento de Ciências Básicas, FZEA, Universidade de São Paulo. \\ 5 Departamento de Reprodução Animal, FMVZ-USP, Pirassununga, São Paulo, Brazil, 13630-000. Phone 55 (19) 3565-4221, Fax \\ 55 (19) 3563-4060.
}

ABSTRACT - The objectives of this study were to validate a non-extractive RIA for seminal testosterone and quantify the hormone using a solid-phase commercial kit, and study the correlation between testosterone in seminal plasma and sperm characteristics. Parallelism showed a correlation index $r=0.992\left(\mathrm{Y}=-5.47+1.073 \mathrm{X} ; \mathrm{R}^{2}=0.985\right)$, indicating that the nonextractive method presented is indicated particularly for assessment of testosterone when establishing comparisons between samples. Overall mean $( \pm \mathrm{SD})$ of testosterone level was $0.60 \pm 0.65 \mathrm{ng} / \mathrm{mL}$. Correlation was only found between the seminal concentrations of testosterone and $\mathrm{pH}$ of the semen.

Key Words: bull, hormone, RIA, semen, spermatozoa, testosterone

\section{Introduction}

Testosterone is the major circulating androgen in males; essential for normal spermatogenenesis and expression of secondary sexual characteristics. It is produced by Leydig cells, almost exclusively from testicular origin (Aümuller \& Seitz, 1990). Sertoli cells are the main target for testosterone, and secrete androgen binding protein (ABP), which binds to the hormone present in the seminal tubule fluid. This event inhibits the absorption by cells in the wall of ductules and ensures the arrival of sufficient testosterone into the epididymus (Ruckebusch et al., 1991; Laudat et al., 1998). Its concentration in seminal plasma correlates to sperm concentration, percentage of motile spermatozoa, and other sperm characteristics (Laudat et al., 1998). Post \& Christensen (1976) and Andersson (1992) observed positive correlation between male serum testosterone and cow pregnancy rates when evaluating fertility of crossbred bulls. Thus, testosterone is an important variable in studies of male fertility, and its determination has been object of research on extraction and chromatography procedures (Schanbacher \& D’Occhio, 1982).

Testosterone has been quantified in several kinds of samples of many animal species by use of radioimmunoassay (RIA). Hormone levels were determined by RIA after ether extraction procedure in serum, testicular interstitial fluid from rats (Sun et al., 1989). Incubated media from testicular tissue of hamsters were assayed by solid-phase RIA kit (Oh et al., 1995). Blood and seminal plasma testosterone of bulls were assessed by enzymatic immunoassay (EIA) after extraction with tertiary butylmethylether (Sauerwein et al., 1992; 2000). Direct RIA has been applied to hypothalamic studies in bull, ram, and rat, and because there is no extraction, chromatography or transfer procedures, the recovery of serum testosterone is $100 \%$ (Schanbacher \& D’Occhio, 1982).

Therefore, the objectives of this study were to determine the $T$ concentration in seminal plasma of mature Simmental bulls, validating a non-extractive RIA technique which employs a solid-phase commercial kit, and to observe the correlation between seminal testosterone and spermatic cells characteristics.

\section{Material and Methods}

Experimental procedures adopted by this experiment are in agreement with Principles of Ethics in Animal Research adopted by the Commission of Bioethics, School of Veterinary Medicine and Animal Science, University of São Paulo (FMVZ/USP, protocol\#403/2003).

Local weather condition was monitored 60 days before and throughout the entire semen collection period. Data of 
air temperature (maximum, minimum and average), relative humidity and solar radiation were obtained every 10 minutes from an in site meteorological station.

Seven weekly semen collections were obtained from 8 purebred Simmental bulls (33 to 41 months age) by electroejaculation (Eletrogen ${ }^{\odot}$, Santa Lydia, Presidente Prudente, Brasil). Each ejaculation was divided in 2 subsamples. The first sub-sample was used to assess $\mathrm{pH}$ through an electronic probe and sperm characteristics, immediately after semen collection. This sub-sample was kept in warmed tubes, and $8 \mu \mathrm{L}$ of semen were placed on pre-warmed slides and motility (\%), vigor (1-5), and mass movement (1-5) were analyzed under $100 \times$ by phase contrast microscopy (Axiostar, Carl Zeiss ${ }^{\circledR}$, Germany). Sperm morphology analysis was realized by humid chamber technique. Another aliquot of the sub-sample was diluted and fixed in pre-warmed $\left(37^{\circ} \mathrm{C}\right)$ formaldehyde buffered saline. After loading with one drop of diluted semen, Neubauer chamber was kept 15 minutes to allow sedimentation of cells before assessment. Evaluation was performed by counting 200 cells under $1,000 \times$ by differential interference microscopy (model 80i, Nikon, Japan). The second subsample was kept in ice for approximately 20 minutes before processing. Seminal plasma was obtained by two-step centrifugation $(500 \mathrm{~g} / 15$ minutes and $6.000 \mathrm{~g} / 15$ minutes at $4{ }^{\circ} \mathrm{C}$ ) and stored in cryogenic tubes at $-20{ }^{\circ} \mathrm{C}$ until assays could be performed.

Determination of testosterone levels in seminal plasma was performed by RIA according to the manufacturer of the commercial kit ACTIVE ${ }^{\mathrm{TM}}$ DSL 4000 RIA (DSL, Webster, Texas, USA). After thawing, $50 \mu \mathrm{L}$ of each sample were transferred to polypropylene test tubes and $500 \mu \mathrm{L}$ of T[ [ $\left.{ }^{125}\right]$ were added following 60 minutes incubation at $37^{\circ} \mathrm{C}$. Tubes were then decanted, inverted on paper towels for 5 minutes, and counted for one minute on the gamma counter. Standards and controls followed the same procedure.

Throughout the study, results were presented as mean values and variation was expressed as standard deviation $( \pm$ SD). Descriptive statistics, ANOVA, and Pearson correlation between testosterone levels and seminal characteristics (mass movement, vigor, motility, sperm abnormalities and $\mathrm{pH}$ ) were achieved using the Statistical Analysis System (SAS, 1995).

\section{Results and Discussion}

During the overall experimental period with animals, including the 60 days before semen collections, average recorded temperatures were $17.6,22.8$, and $29.4{ }^{\circ} \mathrm{C}$, for minimum, average and maximum, respectively. Mean humidity was $73.4 \%$ and mean solar radiation was $384 \mathrm{~W} / \mathrm{m}^{2}$. Observation of climatic data provided valuable information, because it could be verified that animals were constantly exposed to mean temperatures above $22.0^{\circ} \mathrm{C}$ and average maximum temperatures were above $30^{\circ} \mathrm{C}$ in some moments. Relative humidity and solar radiation were also indicative that local weather conditions were typical of tropical climate. Some extreme values for the four parameters were observed around noon during a few days. On the other hand, it must be taken in account that animals were constantly exposed to such climatic conditions, since they remained in the pasture with no shelters to provide shadow. This situation is likely to impair steroidogenesis and spermatogenesis, influencing hormones and cells in semen samples.

Testosterone was detectable even in low concentrations ( 0.02 and $25.0 \mathrm{ng} / \mathrm{mL}$ minimum and maximum sensitivity, respectively) (Table 1). Maximum intra and inter-assay coefficient of variation values were lower than 11.57 and $4.51 \%$, respectively, indicating that results were precise and consistent within and among assays. The correlation index observed in the parallelism verification was $r=0.992$ $\left(\mathrm{Y}=-5.47+1.073 \mathrm{X} ; \mathrm{R}^{2}=0.985\right)$.

The variation in the percentage of bounds of the standard curve and the serial dilutions were parallel, showing parallel dose-response results (Figure 1). The position observed for both standard and serially diluted samples means that the seminal serially diluted samples under investigation resulted in parallel inhibition of the labeled antibody, binding to the antigen to be quantified (testosterone) in a similar pattern to that inhibition observed for the standard samples. No major cross reactions were detected. Schanbacher \& D'Occhio (1982) also reported successful validation of direct RIA for testosterone in serum of five mammalian species, including bulls.

Concentration of testosterone in seminal plasma varied among bulls (Figure 2) and consecutive ejaculations (Figure 3). Minimum and maximum values observed for a single ejaculation along the entire collection period were 0.05 and $2.96 \mathrm{ng} / \mathrm{mL}$, respectively. Overall mean hormone level for multiple ejaculations was $0.60 \pm 0.65 \mathrm{ng} / \mathrm{mL}$. Data reported

Table 1 - Quality control for RIA of T in bovine seminal plasma

\begin{tabular}{lc}
\hline Min. sensibility, \% (ng/mL) & $92.3(0.02)$ \\
Max. sensibility, \% (ng/mL) & $9.9(25.0)$ \\
Low Intra-assay CV, \% & 3.43 \\
High Intra-assay CV, \% & 11.57 \\
Low Inter-assay CV, \% & 4.10 \\
High Inter-assay CV, \% & 4.51
\end{tabular}

CV - Coefficient of variation. 


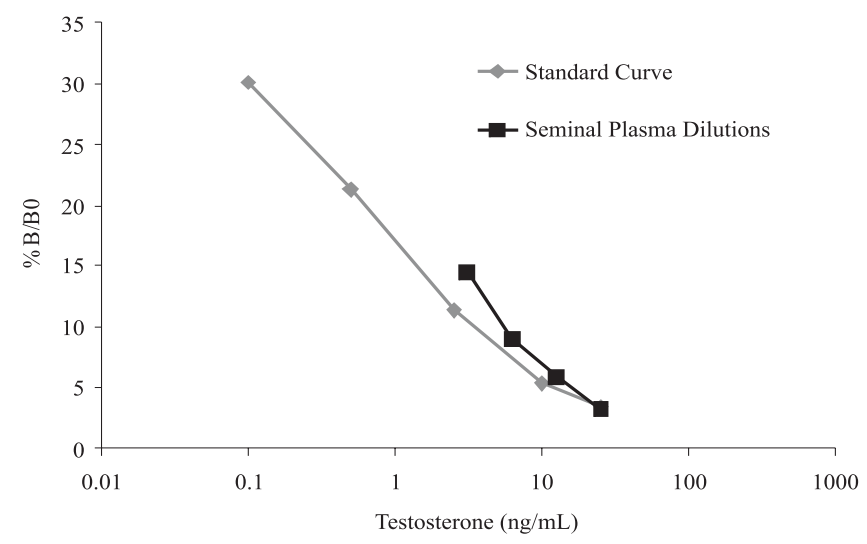

$\mathrm{B}=\mathrm{Blank} ; \mathrm{B} 0=0 \mathrm{ng}$ of testosterone; $\mathrm{B} / \mathrm{B} 0=$ counting rate of sample/counting rate of standard with zero $\mathrm{T}$ ).

Figure 1 - Parallelism test between curves performed with T and serial dilutions containing $100,50,25,12.5$, and $6.25 \%$ of volume of control samples of bovine seminal plasma diluted in PBS BSA 1\%.

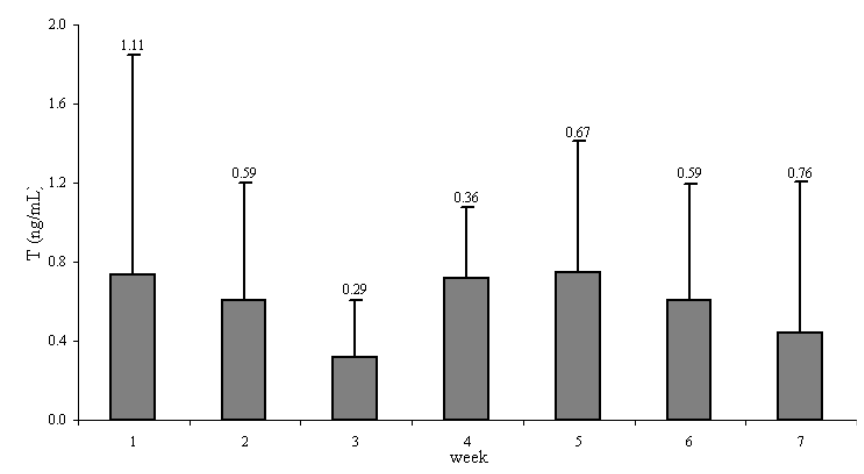

Figure 2 - Mean weekly testosterone levels $( \pm$ STD) and standard deviation in bull seminal plasma $(n=8)$.

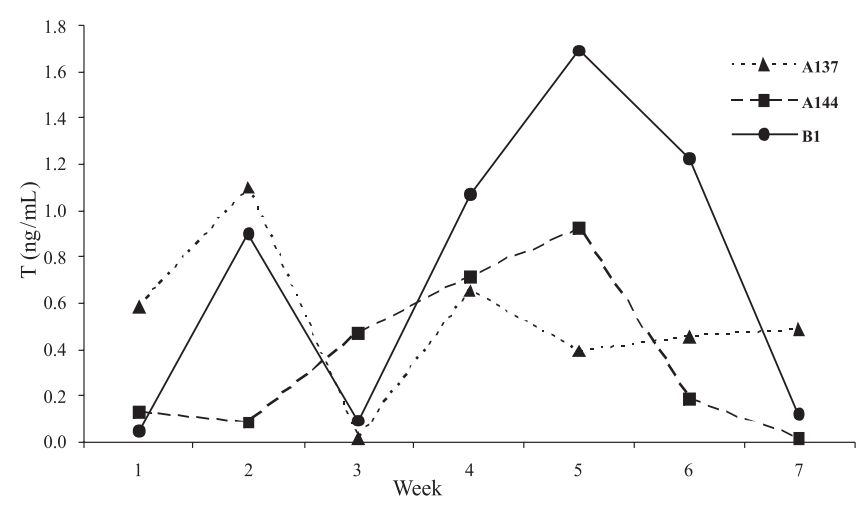

Figure 3 - Variation in testosterone levels $(\mathrm{ng} / \mathrm{mL})$ in seminal plasma of 3 bulls over seven weekly collections. by several authors show some different values in comparison with the present results. Sauerwein et al. (2000) verified that Simmental bulls had from 1.9 to $3.8 \mathrm{ng} / \mathrm{mL}$ of testosterone in the seminal plasma. Testicular tissue was found to have from 0.62 to $2.44 \mathrm{ng} / \mathrm{mg}$ of testosterone (Barth, 1993). Santos et al. (2004) verified that serum concentrations of testosterone in Nelore bulls ranged from 0.80 to $16.7 \mathrm{ng} / \mathrm{mL}$, averaging $4.04 \mathrm{ng} / \mathrm{mL}$. They observed an effect of the moment of sampling $(\mathrm{P}<0.01)$ with a peak of secretion at 9:00 h. Borg et al. (1991) found no significant alterations in testosterone levels associated with sexual behavior, although values were different for Angus bulls with different reproductive behavior performance. Bulls achieving at least 8 mounts and finishing a service showed higher serum concentrations than bulls with less than 8 mounts and non-servicing ( $3.8 \pm 0.1$ and $3.9 \pm 0.1 \mathrm{ng} / \mathrm{mL}$ comparing to $3.7 \pm 0.1$ and $3.3 \pm 0.2 \mathrm{ng} / \mathrm{mL}$, respectively). Borg et al. (1991) also verified that serum levels of testosterone changed before $(4.0 \pm 0.5 \mathrm{ng} / \mathrm{mL})$, during $(3.6 \pm 0.7 \mathrm{ng} / \mathrm{mL})$ and after $(3.6 \pm 0.6 \mathrm{ng} / \mathrm{mL})$ a 30 -minute exposure to an estrous female, although with no significant differences. In the present study, bulls were not exposed to females and were randomly assigned to a constant sequence of semen collection from 8:00 to 16:00 hours. The two variables studied by Borg et al. (1991) were not subject of this research, but they could help to explain the differences observed between the present results and data from literature. It was expected that seminal testosterone would show higher values, based on previous reports and site of testosterone production. One of the possible causes of differences in the results is the interference of seminal proteins. If not removed, the quantity of available hormone for the antigenantibody reaction can be reduced. Individual differences, breed and age are also possible factors causing divergences from previous studies.

Seminal characteristics showed low correlation to seminal testosterone (Table 2). Mass movement and vigor were found to have poor correlation with the androgen in the seminal plasma $(\mathrm{P}>0.05)$. Similarly, motility was not correlated to seminal testosterone $(\mathrm{P}>0.05)$. Santos et al. (2004) also verified low correlation values $(0.32,0.04$ and

Table 2 - Mean seminal characteristics and respective coefficient of correlation with $\mathrm{T}$ concentration in seminal plasma

\begin{tabular}{lccc}
\hline Characteristic & Mean & $\mathrm{r}^{2}$ & $\mathrm{P}$ \\
\hline Mass movement* & 2.7 & 0.1547 & 0.255 \\
Vigor* & 2.9 & 0.1191 & 0.382 \\
Motility (\%) & 68.2 & 0.1240 & 0.363 \\
Sperm abnormalities (\%) & 12.9 & 0.2193 & 0.104 \\
$\mathrm{pH}$ & 6.9 & -0.4048 & 0.002 \\
\hline *Score values from 0 to 5. & & &
\end{tabular}

R. Bras. Zootec., v.40, n.12, p.2721-2724, 2011 
0.25 ) between testosterone and mass movement, vigor, and motility, respectively). It is well known that the hormone is required by accessory sex glands as the prostate. Since their secretions influence seminal composition, it would be reasonable to suppose a relation between its concentration and spermatozoa activity. Total sperm abnormalities did not correlate to seminal testosterone $(\mathrm{P}>0.05)$. Positive correlation between seminal testosterone and total sperm abnormalities was expected, since the role of testosterone on the spermatogenic process is well established. However, Santos et al. (2004) have observed sperm defects having negative correlation $\left(\mathrm{r}^{2}=-0.38, \mathrm{P}<0.05\right)$ to serum levels of testosterone. It is possible that most of the secreted testosterone into seminiferous tubules and local circulation was metabolized at different rates by target cells at different moments.

Seminal testosterone was shown to have a low negative correlation to $\mathrm{pH}(\mathrm{P}<0.01)$. The current knowledge is that cell activity alters seminal $\mathrm{pH}$ and as the hormone-induced metabolism rises, the presence of acidic substances in the medium is increased, reducing the $\mathrm{pH}$ (Mann \& Lutwak-Mann, 1981; Matsuoka et al., 2006). That would explain the inverse correlation between testosterone and seminal $\mathrm{pH}$.

Type of sample, breed environmental and experimental conditions are well known factors which could cause the difference between some of the results from the present report and the current literature. Thus, the authors are conservative, suggesting that RIA without extraction process should be better studied when the objective is to determine the total testosterone concentration in quantitative studies. There is still lack of evidences of the correlation between seminal testosterone and sperm morphology and motility, since the literature is not unanimous on this issue.

\section{Conclusions}

The employment of a solid-phase RIA kit is adequate to assess testosterone in bull seminal plasma, particularly in comparative studies. Mean seminal testosterone observed in Simmental bulls was $0.60 \pm 0.65$, with values varying from $0.32 \pm 0.29$ to $0.75 \pm 0.67 \mathrm{ng} / \mathrm{mL}$. No correlation was observed between seminal testosterone and sperm characteristics.

\section{References}

ANDERSSON, M. Relationships between GnRH-induced Testosterone maxima, sperm motility and fertility in Ayrshire bulls. Animal Reproduction Science, v.27, p.107-111, 1992.

AUMÜLlER, G.; SEITZ, J. Protein secretion and secretory processes in male accessory sex gland secretion. International Review of Cytology, v.121, p.127-231, 1990.

BARTH, A.D. Insights to the pathogenesis of sperm abnormalities in bulls. Revista Brasileira de Reprodução Animal, v.1, n.4, p.1-11. 1993 (supl.).

BORG, K.E.; ESBENSHADE, K.L.; JOHNSON, B.H. Cortisol, Growth Hormone, and Testosterone concentrations during mating behavior in the bull and boar. Journal of Animal Science, v.69, p.3230-3240, 1991

LAUDAT, A.; GUECHOT, J.; PALLUEL, A.M. Seminal androgen concentrations and residual sperm cytoplasm. Clinica Chimica Acta, v.276, p.11-18, 1998 .

MANN, T.; LUTWAK-MANN, C. Biochemistry of spermatozoa: Chemical and functional correlations in ejaculated semen. Andrological aspects. In: MANN, T.; LUTWAK-MANN, C. (Eds.) Male reproductive function and semen. New York: Springer-Verlag. 1981. p.195-268.

MATSUOKA, T.; IMAI, H.; ASAKUMA, S. et al. Changes of fructose concentrations in seminal plasma and glucose and testosterone concentrations in blood plasma in rams over the course of a year. Journal of Reproduction and Development, v.53, n.6, p.805-810, 2006.

OH, S.S.; KHARDORI, R.; KOPPLIN, K. Effects of somatostatin and somatotropin on the in vitro testicular steroidogenesis in hamster. Revista Española de Fisiologia, v.51, n.4, p.187-192, 1995

POST, T.B.; CHRISTENSEN, H.R. Testosterone variability and fertility in bulls. Theriogenology, v.6, p.615-616, 1976.

RUCKEBUSCH, Y.; PHANEUF, L.P.; DUNLOP, R. Hormones of the testes. In: RUCKEBUSCH, Y.; PHANEUF, L.P.; DUNLOP, R. (Eds.). Physiology of small and large animals. Philadelphia: B.C. Decker, 1991. p.556-562.

SANTOS, M.D.; TORRES, C.A.A.; RUAS, J.R.M. et al. Potencial reprodutivo de touros da raça Nelore submetidos a diferentes proporções touro:vaca. Arquivo Brasileiro de Medicina Veterinária e Zootecnia, v.56, n.4, p.497-503, 2004.

SAUERWEIN, H.; MEYER, H.H.D.; SCHAMS, D. Divergent effects of estrogens on the somatotropic axis in male and female calves. Journal of Reproduction and Development, v.38, p.271-278, 1992.

SAUERWEIN, H.; BREIER, B.H.; GALLAHER, B.W. et al. Growth hormone treatment of breeding bulls used for artificial insemination improves fertilization rates. Domestic Animal Endocrinology, v.18, p.145-158, 2000

SCHANBACHER, B.D.; D'OCCHIO, M.J. Validation of a direct radioimmunoassay for testosterone in unextracted derum from five species: Application to study of the hypothalamic-pituitary axis in males. Journal of Andrology, v.3, n.1, p.45-51, 1982.

SANTOS, M.D.; TORRES, C.A.A.; RUAS, J.R.M. et al. Potencial reprodutivo de touros da raça Nelore submetidos a diferentes proporções touro:vaca. Arquivo Brasileiro de Medicina Veterinária e Zootecnia, v.56, n.4, p.497-503, 2004.

SUN, Y.T.; IRBY, D.C.; ROBERTSON, D.M. et al. The effects of exogenously administered testosterone on spermatogenesis in intact and hypophysectomized rats. Endocrinology, v.125, n.2, p. $1000-1010,1989$ 